\title{
Iliopsoas hematoma due to muscular rupture following defibrillation
}

\author{
Artan Jahollari, M.D., ${ }^{1}$ Raif Cavolli, M.D., ${ }^{1}$ Murat Tavlasoglu, M.D., ${ }^{2}$ \\ Ferat Sallahu, M.D., ${ }^{3}$ Shkelzen Muriqi, M.D. ${ }^{4}$ \\ ${ }^{1}$ Department of Cardiovascular Surgery, International Medicine Hospital, Pristina, Kosova \\ ${ }^{2}$ Department of Cardiovascular Surgery, Diyarbakir Military Hospital, Diyarbakir, Turkey \\ ${ }^{3}$ Department of General Surgery, International Medicine Hospital, Pristina, Kosova \\ ${ }^{4}$ Department of Anaesthesia, International Medicine Hospital, Pristina, Kosova
}

\begin{abstract}
We describe a 62 year old patient who presented with acute anterior ischemia and subsequently developed an iliopsoas hematoma. The patient was treated surgically due to rapid progression and femoral neuropathy, and the iliopsoas muscle rupture was diagnosed intraoperatively. The rupture was related to the external electrical defibrillation the patient had on admission. This was a rare case, and we hope the report would help to raise physicians' awareness regarding this complication and treatment.
\end{abstract}

Key words: Defibrillation; hematoma; iliopsoas rupture.

\section{INTRODUCTION}

Iliopsoas hematoma is a rarely seen form of retroperitoneal hemorrhage. The causes are various and the treatment differs based on the underlying pathology and clinical situations of the patient.

We herein report the case of a patient who was admitted with acute anterior ischemia and afterward developed an iliopsoas hematoma. The patient underwent an operation and identified with an iliopsoas rupture, which was related to external electrical defibrillation. We could not find a similar case reported in the medical literature, and we think that our case report may be the first of its kind to be published.

\section{CASE REPORT}

A 62-year-old male patient, who presented with severe

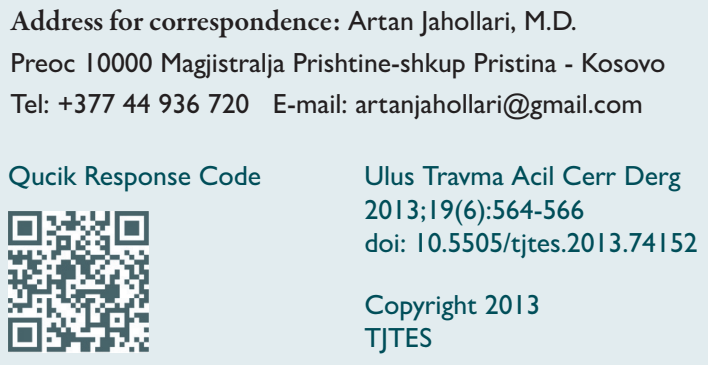

retrosternal pain, was diagnosed with acute anteroseptal ischemia. Several minutes after his admission he experienced ventricular fibrillation and was immediately converted with a single 200 joule shock of a biphasic defibrillator. Emergent coronary angiography via the right femoral artery was performed, revealing total thrombotic occlusion of the proximal LAD (left anterior descending artery) which was treated successfully with $\mathrm{PCl}$ (percutaneous coronary intervention). 5000 IU of unfractioned heparin was administered intravenously during the procedure and the following treatment included subcutaneous LMWH (low molecular weight heparin, enoxaparine sodium 6000 anti-Xa IU/0.6 ml, twice a day), aspirin $100 \mathrm{mg} /$ day and clopidogrel $75 \mathrm{mg} /$ day. On the 2nd day he complained of left flank pain and a decrease in hemoglobin was observed. An abdominal ultrasound revealed the presence of a left retroperitoneal hematoma. The magnetic resonance imaging (MRI) showed a large hematoma of the left iliopsoas muscle (Figure I). Anticoagulants and antiagreggants were immediately stopped and the patient was followed conservatively, supplied with fresh frozen plasma and fresh blood. Despite ruling out active gross hemorrhage by a radial angiogram, the progressive decrease of hemoglobin persisted and the pain severity increased, radiating to the left leg. He developed abdominal defense and paresis of the left leg, which was attributed to femoral neuropathy. Urgent surgery consisting of a laparatomic exploration was performed on the 4th day. Approximately $1000 \mathrm{ml}$ of aspirated fluid was collected from the retroperitoneal area. The psoas fascia was incised and a 


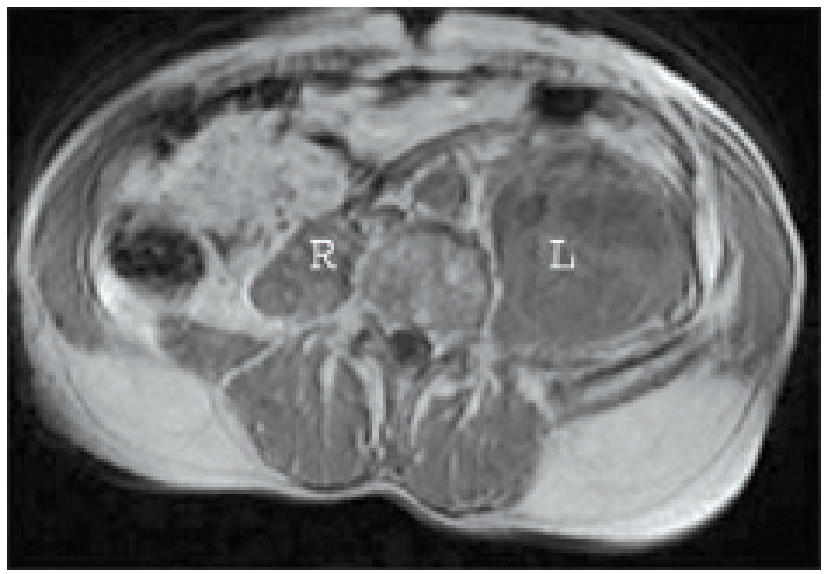

Figure 1. Axial view of MRI showing large hematoma of left iliopsoas muscle.

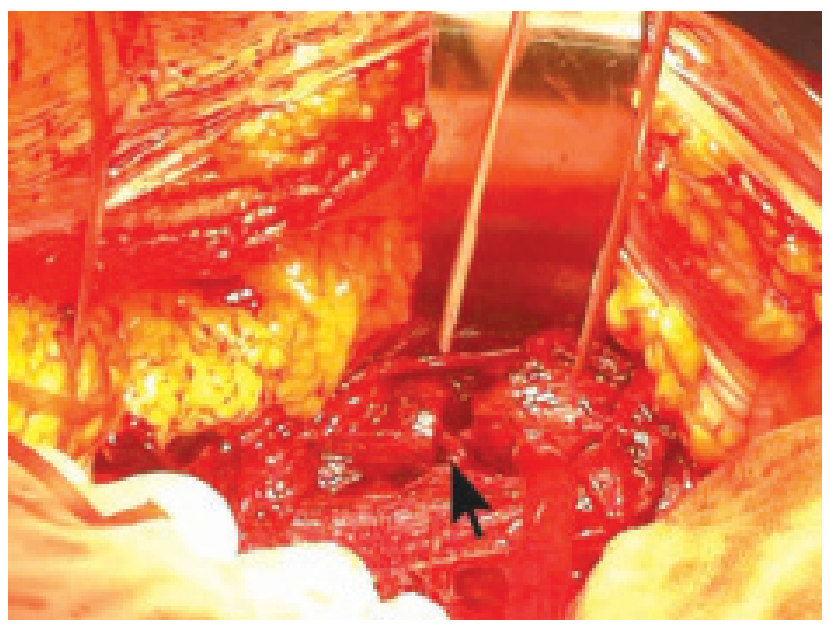

Figure 2. Intraoperative view of the ruptured iliopsoas.

mixture of $1000 \mathrm{ml}$ of liquefied and clotted blood was removed. Rupture of the muscle fibers was observed and intact muscle parts were sutured together (Figure 2). During the postoperative period he was treated with LMWH (enoxaparine sodium 6000 anti-Xa IU/0.6 ml, daily). He had a rapid recovery and was discharged after 5 days on antiaggregant therapy (aspirin $100 \mathrm{mg} /$ day and clopidogrel $75 \mathrm{mg} /$ day).

\section{DISCUSSION}

Hematoma of the iliopsoas muscle is a rare and challenging condition. Anticoagulant use, hemophilia, trauma, alcoholic cirrhosis, etc. appear to be some of the main causes. ${ }^{[1-3]}$ However, the nature of this pathology is not fully understood and a many cases develop spontaneously. ${ }^{[4]}$ Clinical manifestation includes abdominal and flank pain, abdominal distention and defense, hemorrhagic shock features, and leg or groin pain in presence of femoral nerve compression. Abdominal ultrasound provides a first glance and quick information about the ongoing condition. However, more specific tools, such as MRI and CT-scan, are necessary to confirm the pathology and help to make a proper decision.
There are different treatment modalities for iliopsoas hematomas. Good outcomes of conservative therapy have been successfully reported, and we agree that this is the first choice in stable patients. Patients suffering from hemophilia or that are under anticoagulant therapy seem to benefit the most from this choice. Local puncture can also be applied to drain the hematoma, but it carries the risk of further complications and is not helpful in removing clotted blood. Selective embolization of active branch bleeding is an option in selected patients and requires expertise. However, the definite treatment in complicated and unstable patients remains surgery. The presence of severe pain and the development of neurologic symptoms due to compression and hemorrhagic shock are some of the main indications for surgical decompression. Different sources strongly support the evacuation of the hematoma immediately after the onset of femoral neuropathy, and associate it with a great likelihood of a return to pre-event neurological status. ${ }^{[5-7]}$ In our case, surgery was obligatory by abdominal defense, femoral neuropathy, and hemodynamic progression; all together compromising the general situation. Despite the delicate heart condition, our patient tolerated the surgery well and recovered quickly.

During the surgery we discovered that rupture of the iliopsoas was the reason for the hematoma. Although it helped to increase the hemorrhage, anticoagulant usage cannot be blamed, as it does not explain the rupture of the muscle. On the other hand, defibrillation was the only physical trauma the patient experienced and it is a well-known fact that it provokes skeletal muscle contractions. ${ }^{[8]}$ The psoas major muscle itself originates at the vertebral bodies of TI 2 and LI-L5 and their associated intervertebral discs, a region anatomically close to the apical defibrillator pad. External electrical defibrillation is an old and safe treatment modality in ventricular fibrillation, and very few cases with mechanical complications of external defibrillation have been reported. Most complications include skin burns, but bone and muscle involvement have also been described, including sternal ${ }^{[9]}$ and vertebral fractures, ${ }^{[10]}$ myocardial lesions, ${ }^{[1]}$ and pectoral muscle necrosis. $^{\left[{ }^{12]}\right.}{ }^{11}$ liopsoas rupture due to defibrillation has not been previously reported and although it is a rare complication, it must be kept in mind owing to its potential severity.

As a result, we herein described a rare case of iliopsoas hematoma due to muscular rupture. We strongly believe that the rupture resulted as a complication of external defibrillation. Conservative treatment is the therapy of choice in iliopsoas hematomas. However, surgery should be considered in rapidly progressing, neurologically complicated and hemodynamically unstable cases.

\section{Conflict of interest: None declared.}

\section{REFERENCES}

1. Zago G, Appel-da-Silva MC, Danzmann LC. Iliopsoas muscle hema- 
toma during treatment with warfarin. [Article in Portuguese] Arq Bras Cardiol 2010;94:1-3. [Abstract] [CrossRef]

2. Dauty M, Sigaud M, Trossaërt M, Fressinaud E, Letenneur J, Dubois C. Iliopsoas hematoma in patients with hemophilia: a single-center study. Joint Bone Spine 2007;74:179-83. [CrossRef]

3. Sugiyama C, Akai A, Yamakita N, Ikeda T, Yasuda K. Muscle hematoma: a critically important complication of alcoholic liver cirrhosis. World J Gastroenterol 2009;15:4457-60. [CrossRef]

4. Marquardt G, Barduzal Angles S, Leheta F, Seifert V. Spontaneous haematoma of the iliac psoas muscle: a case report and review of the literature. Arch Orthop Trauma Surg 2002;122:109-11. [CrossRef]

5. Parmer SS, Carpenter JP, Fairman RM, Velazquez OC, Mitchell ME. Femoral neuropathy following retroperitoneal hemorrhage: case series and review of the literature. Ann Vasc Surg 2006;20:536-40. [CrossRef]

6. Nakao A, Sakagami K, Mitsuoka S, Uda M, Tanaka N. Retroperitoneal hematoma associated with femoral neuropathy: a complication under antiplatelets therapy. Acta Med Okayama 2001;55:363-6.
7. Guivarc'h M. Hematoma of the iliac psoas muscle. 29 cases. [Article in French] J Chir (Paris) 1997;134:382-9. [Abstract]

8. Kim Y, Schimpf PH. Electrical behavior of defibrillation and pacing electrodes. Proceedings of the IEEE 1996;84:446-56. [CrossRef]

9. Vollmann D, Lüthje L, Seegers J, Sohns C, Dorenkamp M, Vafa A, et al. Sternal fracture after elective electrical cardioversion of atrial fibrillation. Clin Res Cardiol 2011;100:261-2. [CrossRef]

10. Giacomoni P, Cremonini R, Cristoferi E, Guardigli C, Gulinelli E, Matarazzo $\mathrm{V}$, et al. Vertebral fracture caused by electric cardioversion. [Article in Italian] G Ital Cardiol 1987;17:543-5. [Abstract]

11. Liaudet L, Kehtari R, Enrico JF. Myocardial lesion secondary to defibrillation. Literature review and practical implications. [Article in French] Rev Med Suisse Romande 1993;113:933-43. [Abstract]

12. Vogel U, Wanner T, Bültmann B. Extensive pectoral muscle necrosis after defibrillation: nonthermal skeletal muscle damage caused by electroporation. Intensive Care Med 1998;24:743-5. [CrossRef]

\section{OLGU SUNUMU - ÖZET}

\section{Defibrilasyon sonrası gelişen kas yırtığına bağlı iliopsoas hematomu}

\section{Dr. Artan Jahollari, ${ }^{1}$ Dr. Raif Cavolli, ${ }^{1}$ Dr. Murat Tavlasoglu, ${ }^{2}$ Dr. Ferat Sallahu, ${ }^{3}$ Dr. Shkelzen Muriqi ${ }^{4}$}

${ }^{1}$ International Medicine Hospital, Kalp ve Damar Cerrahisi Bölümü, Pristina, Kosova

${ }^{2}$ Diyarbakır Asker Hastanesi, Kalp ve Damar Cerrahisi Bölümü, Diyarbakır, Türkiye

IInternational Medicine Hospital, Genel Cerrahi Bölümü, Pristina, Kosova

${ }^{4}$ International Medicine Hospital, Anestezi Bölümü, Pristina, Kosova

Bu yazıda, akut anterior iskemi ile başvuran ve ardında iliopsoas hematomu gelişen 62 yaşında bir hasta sunuldu. Çabuk ilerleme ve femoral nöropati gelişmesi nedeniyle hasta cerrahi olarak tedavi edildi ve ameliyat sırasında iliopsoas kas yırtığı tespit edildi. Kas yırtığı, kabul esnasında uygulanan eksternal elektrik defibrilasyonla ilişkilendirildi. Bu nadir olgu sunumunun bu komplikasyon ve tedavisinin hakkında hekimlerin farkındalığın artıracağını ummuyoruz.

Anahtar sözcükler: Defibrilasyon; hematom; iliopsoas yırtı̆ı̆.

Ulus Travma Acil Cerr Derg 2013;19(6):564-566 doi: 10.5505/tjtes.2013.74152 